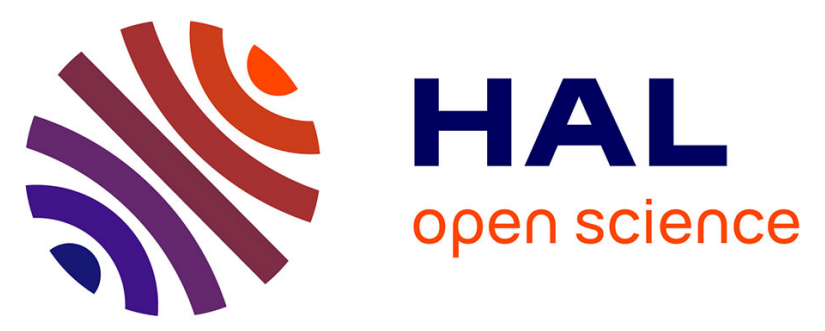

\title{
Evidence of genotype-diet interactions in the response of rainbow trout (Oncorhynchus mykiss) clones to a diet with or without fishmeal at early growth
}

Mathilde Dupont-Nivet, Françoise Médale, Julien Leonard, Sandrine Le Guillou, Franck Tiquet, Edwige Quillet, Inge Geurden

\section{To cite this version:}

Mathilde Dupont-Nivet, Françoise Médale, Julien Leonard, Sandrine Le Guillou, Franck Tiquet, et al.. Evidence of genotype-diet interactions in the response of rainbow trout (Oncorhynchus mykiss) clones to a diet with or without fishmeal at early growth. Aquaculture, 2009, 295 (1-2), pp.15-21. 10.1016/j.aquaculture.2009.06.031 . hal-01193406

\section{HAL Id: hal-01193406 \\ https://hal.science/hal-01193406}

Submitted on 30 May 2020

HAL is a multi-disciplinary open access archive for the deposit and dissemination of scientific research documents, whether they are published or not. The documents may come from teaching and research institutions in France or abroad, or from public or private research centers.
L'archive ouverte pluridisciplinaire HAL, est destinée au dépôt et à la diffusion de documents scientifiques de niveau recherche, publiés ou non, émanant des établissements d'enseignement et de recherche français ou étrangers, des laboratoires publics ou privés. 
Provided for non-commercial research and education use. Not for reproduction, distribution or commercial use.

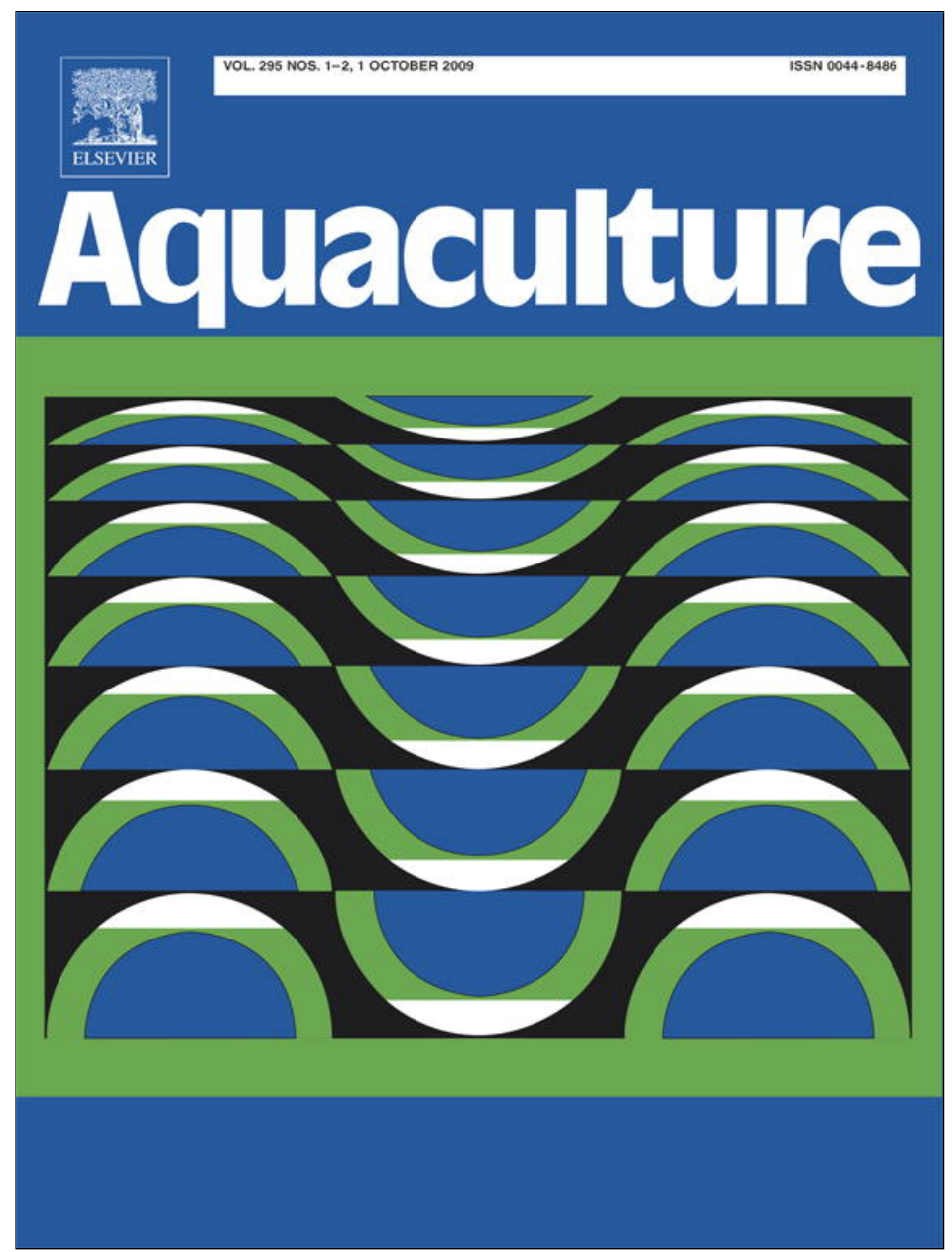

This article appeared in a journal published by Elsevier. The attached copy is furnished to the author for internal non-commercial research and education use, including for instruction at the authors institution and sharing with colleagues.

Other uses, including reproduction and distribution, or selling or licensing copies, or posting to personal, institutional or third party websites are prohibited.

In most cases authors are permitted to post their version of the article (e.g. in Word or Tex form) to their personal website or institutional repository. Authors requiring further information regarding Elsevier's archiving and manuscript policies are encouraged to visit:

http://www.elsevier.com/copyright 


\title{
Evidence of genotype-diet interactions in the response of rainbow trout (Oncorhynchus mykiss) clones to a diet with or without fishmeal at early growth
}

\author{
Mathilde Dupont-Nivet ${ }^{\mathrm{a}, *}$, Françoise Médale ${ }^{\mathrm{b}}$, Julien Leonard ${ }^{\mathrm{a}}$, Sandrine Le Guillou ${ }^{\mathrm{a}}$, Franck Tiquet ${ }^{\mathrm{c}}$, \\ Edwige Quillet ${ }^{\mathrm{a}}$, Inge Geurden ${ }^{\mathrm{b}}$ \\ a INRA, UMR 1313 Génétique Animale et Biologie Intégrative, F-78350 Jouy-en-Josas, France \\ ${ }^{\mathrm{b}}$ INRA, UMR1067, Laboratoire de Nutrition, Aquaculture et Génomique, F-64310 St Pée-sur-Nivelle, France \\ ' INRA, UE750, Unité Expérimentale Piscicole, F-78350 Jouy-en-Josas, France
}

\section{A R T I C L E I N F O}

\section{Article history:}

Received 25 November 2008

Received in revised form 16 June 2009

Accepted 18 June 2009

\section{Keywords:}

Rainbow trout

Oncorhynchus mykiss

Isogenic lines

Plant-protein source

Fishmeal replacement

Genotype environment interaction

Growth

\begin{abstract}
A B S T R A C T
This study examined the genetic variability and genotype $\times$ diet interactions during early growth (initial mean body weight $1.2 \mathrm{~g}$ ) among seven heterozygous clones of rainbow trout, Oncorhynchus mykiss. The clones were hand-fed a diet containing either fishmeal or plant proteins during a 49-day trial divided into two periods (P1, 26 days, and P2, 23 days). Weight, variation of weight within clone, feed intake, feed efficiency and mortality were calculated for both periods.

There was a highly significant effect of diet and of clone for all traits at both periods, except for feed efficiency and mortality at P1. Highly significant interactions between diet and clone were also recorded for all these traits, except for mortality at P1. The occurrence of genotype $\times$ diet interactions when feeding juvenile rainbow trout with an all plant-protein diet indicates that a highly performing genotype on a fishmeal diet may perform poorly when fed a plant-protein diet. Interactions were found for the two major determinants of growth, i.e. feed intake and feed efficiency, showing that the dietary response differs according to the genotype. Monitoring of the within-clone variability of weight showed that a plant-based diet is likely to enhance the overall phenotypic variance in a population, whatever its initial genetic variability.
\end{abstract}

(c) 2009 Elsevier B.V. All rights reserved.

\section{Introduction}

Intensification and development of the aquaculture industry depends on the use of sustainable protein sources as alternatives for fishmeal in aquafeeds (Naylor et al., 2000; Gatlin et al., 2007). In salmonids, several studies replaced part (33-75\%, Carter and Hauler, 2000; Storebakken et al., 2000; Espe et al., 2006) or all (100\%, Kaushik et al., 1995; Watanabe et al., 1998; Yamamoto et al., 2002) of the fishmeal by alternate proteins without significant growth reductions. However, depressed performances, especially at high levels of plant protein have been reported in other studies (Gomes et al., 1995; Médale et al., 1998; de Francesco et al., 2004; Barrows et al., 2007), which highlight the need to optimize intakes and nutritional value of plant-based diets for salmonids. Suggested approaches concern better selection and processing techniques of the ingredients or genetic manipulation of the raw materials (Gatlin et al., 2007).

The cited studies, however, considered the mean performance of the studied populations, but not the within population variability of traits and its genetic basis. Indeed, another way to tackle the problem of decreased performance is to explore the potential of selection programs on the aptitude of fish to use plant-based diets (Gatlin et al., 2007). The

\footnotetext{
* Corresponding author. Tel.: +331 34652349; fax: +33 134652390. E-mail address: mathilde.dupont-nivet@jouy.inra.fr (M. Dupont-Nivet).
}

genetic variability for growth in fish fed plant proteins has been little studied, except recently in rainbow trout Oncorhynchus mykiss (Palti et al., 2006; Pierce et al., 2008) and European whitefish Coregonus lavaretus (Quinton et al., 2007a,b). All studies concluded to the existence of additive genetic variability for growth on plant-protein diets, suggesting that genetic progress is possible by selection. To be noted however is that the plant-protein diets in latter studies still contained some marine protein source even if it was only during early growth (Palti et al., 2006).

Up to date, most commercial breeding schemes for growth have been performed on fish fed diets containing fishmeal. Yet, differences in rankings of families due to a change in dietary protein source (i.e. genotype $\times$ diet interactions) could have a drastic impact on the future of these selected lines. Information on the existence of genotype-diet interactions, when substituting fishmeal by plant protein, is limited. In a recent study with European whitefish, no significant diet $\times$ genotype interaction was evidenced when comparing a diet with fishmeal to a diet in which soybean meal replaced $50 \%$ of the fishmeal (Quinton et al., 2007a,b). This agrees with Palti et al. (2006), who tested higher substitution levels and who noted no significant difference in family rankings of rainbow trout when fed a gluten-based or a fishmeal-based diet. In contrast, a significant genotype $\times$ diet interaction in the family growth response of rainbow trout was found by Pierce et al. (2008), pointing towards the risk of losing genetic progress when feeding alternate protein to strains selected in a traditional fishmeal environment. 
The aim of the present study was to examine the existence of genetic variability and genotype $\times$ diet interactions in rainbow trout fed a diet with fishmeal or plant proteins. The experimental conditions were chosen to enhance both diet and genotype effects. With regard to the diet, two extreme experimental formulations were tested, i.e. a diet with only fishmeal as protein source versus an isoproteic diet totally devoid of fishmeal containing a blend of plant-protein sources. Moreover, the diets were given at an early growth stage (initial weight of $1.2 \mathrm{~g}$ ), during which the fish are highly responsive to dietary changes because of their high growth potential.

With regard to the genotype, we used clones. Since all animals within each clone are genetically identical, measures of the performances of each group reflect the performances of each individual genotype. This not only increases the precision of individual traits like growth, but also allows measuring feed intake and feed efficiency of each genotype. In fish genetics, these two parameters, essential for understanding growth differences between genotypes, are rarely discerned. This is mainly due to the difficulty to measure individual feed intakes in fish, except by means of X-rays (e.g. in Quinton et al., 2007a,b; Grima et al., 2008). Secondly, again because all individuals are genetically identical, additive genetic variance within a clone is null and the phenotypic variance of a trait provides a direct measure of environmental variance, i.e. the tolerance of a genotype (the clone genotype) to the environment. A further advantage of the use of clones is that exactly the same genotypes can be produced for future trials since the parental genotypes belong to well established homozygous clonal lines (Quillet et al., 2007).

\section{Materials and methods}

\subsection{Experimental diets}

The two experimental diets were manufactured using a twinscrew extruder (Clextral, France) at the experimental fish farm of the French National Institute of Agronomy Research (INRA, Donzacq, France). Diet V0 contained fishmeal as sole protein source, whereas the fishmeal-free diet V100 contained a blend of wheat gluten meal, corn gluten meal, soybean meal and white lupin as protein sources (Table 1). Although not of commercial practice, diet V0 was formulated to contain no plant-protein source in order to compare the genotype response to a full fishmeal versus plant-protein diet. Synthetic L-lysine and phosphorous salts were added to diet V100 to correct the deficiency in essential amino acid and phosphorous supply. Both diets had a similar amount of crude protein. Extra fish oil was added to diet V100, compensating for the residual fat content in the fishmeal, in order to render the diet isolipidic.

\subsection{Experimental animals}

The breeders were homozygous fish issued from the INRA 'synthetic' strain (SY) of rainbow trout (O. mykiss), expected to contain a large level of genetic variability (Quillet et al., 2007). Seven heterozygous clones were obtained by mating a single homozygous female clonal line with seven individual homozygous males from seven other clonal lines. The use of the same maternal (same genome) line for the seven experimental clones avoided initial maternal effects associated to egg size and hatching time. Ova had to be collected from different females from the same clonal line in order to produce a sufficient number of fish. In order to further minimize maternal effects, seven females with similar mean egg size (ranging from 54 to $58 \mathrm{mg}$ ) were chosen among 28 collected on the same day. Mating was classically carried out by collecting gametes on anaesthetized breeders to perform external fertilization. The ova were carefully mixed and then divided into seven groups, each one being fertilized by one of the seven males. Thus, differences between clones are only to be attributed to the genetic variability brought by the male pathway, without being biased by maternal effects.
Homozygosity of all breeders and isogenicity of females were checked using allelic variation at four polymorphic microsatellite markers for dams and nine for sires.

The fertilized eggs were incubated at $10{ }^{\circ} \mathrm{C}$. At the eyed (embryo) stage, each clone was divided into three replicates and reared in 251 aquaria (recirculated system, $10{ }^{\circ} \mathrm{C}$ constant). After yolk resorption, the fry were fed a commercial trout diet (Bio-Optimal Start, Biomar France) from first-feeding until the start of the feeding trial (76 days post first-feeding).

\subsection{Feeding trial and measured traits}

At the start of the experiment, each of the seven clones was divided into six groups of 105-110 fish each. The initial body weight of the fish was $1.20 \pm 0.26 \mathrm{~g}$. Three replicates of each clone were fed the fishmeal-based diet (V0) while the three others received the plantbased diet (V100). Each group was randomly allocated to one of the 42 aquaria $(25 \mathrm{l})$ in the same closed recirculating system $\left(10^{\circ} \mathrm{C}\right.$ constant).

The feeding trial was divided into two periods (P1 and P2) which lasted 26 and 23 days respectively, corresponding to 24 and 21 days of feeding. Because of the onset of mortality at the end of P2 (see Results section), the trial was continued for 14 days (period 3, P3) with fish fed ad libitum. Here (P3), only mortality was recorded in order to monitor the genetic variability of this trait. The fish were left unfed for two days during the weight measurements, which took place at the start of the experiment and at the end of each period. All fish from each aquarium were weighed individually for the determination of individual body weights and the coefficient of variation (CV, \%). Mortality was monitored every day. Fish were fed three times daily (10 a.m., 13 p.m. and 17 p.m.). The glass front of the aquaria allowed an accurate observation of feed intake. Periods of ad libitum feed distributions, where fish were carefully fed by hand until visual satiation (until pellets reached the bottom of the aquarium), were alternated with periods of pre-weighed feed ration distributions ('restricted feeding', Fig. 1) with the aim to reduce the feeding work

Table 1

Formulae and analytical composition of the experimental diets (V0: fishmeal-based diet, V100: all fishmeal replaced by plant protein sources).

\begin{tabular}{|c|c|c|}
\hline Diet & V0 & V100 \\
\hline \multicolumn{3}{|l|}{ Ingredients ( $\mathrm{g} / \mathrm{kg})$} \\
\hline Fishmeal LT $94^{\mathrm{a}}$ & 472 & 0 \\
\hline White sweet lupin (CP $40 \%)^{b}$ & 0 & 100 \\
\hline Corn gluten meal $(\mathrm{CP} 62 \%)^{c}$ & 0 & 150 \\
\hline Wheat gluten $(\mathrm{CP} 80 \%)^{d}$ & 0 & 250 \\
\hline Extruded whole wheat $(\mathrm{CP} 10 \%)^{c}$ & 362 & 94 \\
\hline Extruded dehulled peas (CP 24\%) & 0 & 24 \\
\hline Soybean meal $(\mathrm{CP} 46 \%)^{\mathrm{c}}$ & 0 & 120 \\
\hline L-Lysine ${ }^{f}$ & 0 & 11 \\
\hline CaHPO4.2H20 (18\%P) & 0 & 43 \\
\hline Fish oil ${ }^{\text {a }}$ & 160 & 202 \\
\hline Mineral and vitamin premix ${ }^{g}$ & 6 & 6 \\
\hline \multicolumn{3}{|l|}{ Analytical composition } \\
\hline Dry matter (g/kg WW) & 934.7 & 925.7 \\
\hline Crude protein (g/kg DM) & 392.6 & 445.7 \\
\hline Crude lipids (g/kg DM) & 220.9 & 208.8 \\
\hline Gross energy (MJ/kg DM) & 23.3 & 24.6 \\
\hline Ash (g/kg DM) & 82.6 & 58.4 \\
\hline Phosphorus (g/kg DM) & 12.8 & 11.7 \\
\hline
\end{tabular}

a Sopropêche, Lorient, France.

b Terrena Cooperative, Ancenis, France (Farilup500).

c Inzo, Argentan, France (Cerestar 13864;Soja 48).

d Roquette, Lestrem, France (Vital wheat gluten).

e Sotexpro, Hermonville, France (Aquatex 8071).

f Eurolysine, Paris, France.

g According to NRC (1993) 


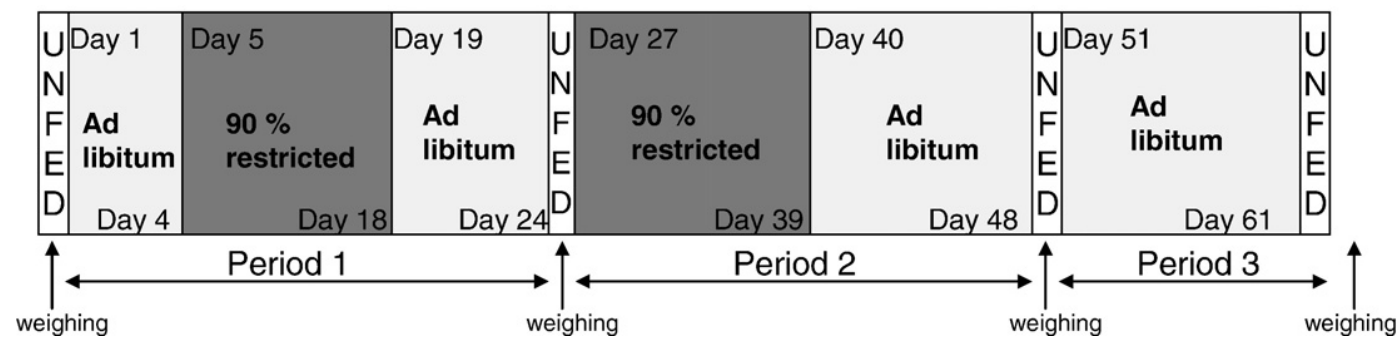

Fig. 1. Occurrences of ad libitum and restricted feed distributions during the experimental period.

load. The pre-weighed feed ration corresponded to $90 \%$ of the mean amount of feed ingested by each fish group of each tank during the ad libitum distribution and was divided over the three daily meals. It was supplied by hand and here also special care was taken so that no food was wasted. The feed ration was recalculated on a weekly basis by estimating the body mass gain (taking into account a mean feed efficiency of 1.2).

Daily feed intakes (DFI) in each period were expressed on an individual basis as $\mathrm{mg}$ feed ingested per day per fish. Feed efficiencies (FE) were calculated for each period by dividing the body mass gain by the total feed intake during that period. Thus, for each clone, three values (one for each replicate) of DFI and FE were available per diet and period.

\subsection{Statistical analysis}

For each period, the effects of clone, diet and clone*diet interaction on cumulated percentage of mortality, body weight, CV of body weight, DFI and FE were tested using ANOVA or ANCOVA (for DFI with the initial weight of each period as a covariable). An angular transformation and a logarithmic transformation were applied to the raw values of mortality and DFI, respectively. For CV, no transformation was applied since it was not skewed as it can be feared for a trait expressed in percentage. For body weight, a replicate effect was added resulting in the following model:

$W_{i j k l}=\mu+$ clone $_{i}+$ diet $_{j}+$ clone $^{*}$ diet $_{i j}+$ replicate $_{i k}+e_{i j k l}$

where $\mu$ was the general mean, clone ${ }_{i}$ the clone effect, diet ${ }_{j}$ the diet effect, clone ${ }^{*}$ diet $_{i j}$, the interaction between diet and clone, replicate ${ }_{i k}$, the replicate effect nested within clone and $e_{i j k l}$ the residual error. For
F-tests, clone effect was tested taking into account the replicate effect as the error term.

GLM procedure of $S A S \circledR$ software was used to perform the analyses.

\section{Results}

\subsection{Recorded traits}

Table 2 summarizes the overall means (with standard deviations) and the genotype-dependent minimum and maximum values of the different traits recorded in each diet. During the first two periods, the body weight more than quadrupled for fish fed diet $\mathrm{V} 0$ and more than doubled for fish fed diet V100. These differences in body weight resulted from differences in both DFI and FE. Results of the ANOVA and ANCOVA are reported in Table 3. Except for FE and mortality in P1, all effects i.e. clone, diet and clone* diet were highly significant for all traits.

At the end of period P3, cumulated mortality for each clone and diet is reported in Table 4 . The mortality with diet V0 was low $(<3.5 \%)$ and unaffected by the genotype $(P=0.21)$. Important mortality was seen with diet V100 during P3. This resulted in a significant diet effect on mortality $(P<0.02)$ for clones $91,97,107,110$ and 120 . Yet, within diet V100, there was a highly significant clone effect $(P<0.0001)$ on mortality, with clones 97, 91 and 107 having the highest mortalities (50.6, 39.4 and $25.5 \%$ of cumulated mortality, respectively) and clones 79 and 83 the lowest (3.0 and $6.2 \%$ respectively). Thus, further in this paper, only results from P1 and P2 are considered.

Due to the significant interactions $(P<0.017$, Table 3$)$ found for the parameters detailed in Table 5 (body weight, CV, feed intake and feed efficiency), the significance of the main effects (clone and diet) on

Table 2

Elementary statistics for each trait in clonal rainbow trout fed diet V0 (fishmeal diet) or diet V100 (all fishmeal replaced by plant protein) per period (P1, P2 or P3).

\begin{tabular}{|c|c|c|c|c|c|c|c|c|}
\hline & \multicolumn{2}{|l|}{$N$} & \multicolumn{2}{|l|}{ Mean \pm SD } & \multicolumn{2}{|l|}{ Min } & \multicolumn{2}{|l|}{ Max } \\
\hline & $\overline{\mathrm{V} 0}$ & $\overline{V 100}$ & $\overline{\mathrm{V} 0}$ & V100 & $\overline{\mathrm{V} 0}$ & $\overline{V 100}$ & $\overline{\mathrm{V} 0}$ & $\mathrm{~V} 100$ \\
\hline Initial weight & 4404 & & $1.20 \pm 0.26$ & & 1.10 & & 1.31 & \\
\hline Initial CV of weight (\%) & & & 20.1 & & 16.4 & & 23.8 & \\
\hline \multicolumn{9}{|l|}{ Period P1 } \\
\hline Final weight (g/fish) & 2274 & 2232 & $2.83 \pm 0.58$ & $2.31 \pm 0.60$ & 2.47 & 1.94 & 3.21 & 2.64 \\
\hline CV of weight (\%) & 21 & 21 & $18.5 \pm 2.4$ & $23.0 \pm 3.9$ & 15.5 & 17.1 & 20.4 & 30.1 \\
\hline Feed intake (mg/fish/d) & 21 & 21 & $56.6 \pm 6.2$ & $37.9 \pm 6.2$ & 49.9 & 30.1 & 68.1 & 45.0 \\
\hline Feed efficiency & 21 & 21 & $1.25 \pm 0.05$ & $1.27 \pm 0.10$ & 1.20 & 1.11 & 1.30 & 1.38 \\
\hline Mortality (\%) & 21 & 21 & $0.57 \pm 0.94$ & $1.48 \pm 1.76$ & 0 & 0.3 & 1.5 & 3.3 \\
\hline \multicolumn{9}{|l|}{ Period P2 } \\
\hline Final weight (g/fish) & 2271 & 2006 & $5.21 \pm 1.21$ & $3.18 \pm 0.92$ & 4.51 & 2.54 & 6.53 & 4.02 \\
\hline CV of weight (\%) & 21 & 21 & $19.6 \pm 2.2$ & $24.8 \pm 4.6$ & 16.9 & 17.9 & 21.9 & 31.4 \\
\hline Feed intake (mg/fish/d) & 21 & 21 & $95.6 \pm 13.1$ & $44.7 \pm 8.9$ & 79.0 & 32.9 & 122.5 & 59.4 \\
\hline Feed efficiency & 21 & 21 & $1.13 \pm 0.09$ & $0.81 \pm 0.19$ & 0.96 & 0.47 & 1.22 & 1.05 \\
\hline Mortality (\%) & 21 & 21 & $0.30 \pm 1.16$ & $8.9 \pm 12.1$ & 0 & 1.21 & 1.5 & 32.8 \\
\hline \multicolumn{9}{|l|}{ Period P3 } \\
\hline Mortality (\%) & 21 & 21 & $0.47 \pm 0.87$ & $8.13 \pm 11.7$ & 0 & 1.23 & 3.06 & 37.8 \\
\hline Cumulated mortality (\%) & 21 & 21 & $1.4 \pm 1.2$ & $22.1 \pm 17.5$ & 0 & 3.0 & 3.3 & 50.6 \\
\hline
\end{tabular}

The mean represents the average value $( \pm \mathrm{SD})$ per diet. The minimum and maximum represent the minimum or maximum clone mean within each dietary group. 
Table 3

$P$ values showing the effect of the genotype (7 rainbow trout clones), of the diet (V0, V100) and the interaction clone $\times$ diet at the end of each period (P1, P2 or P3) for each trait (ANOVA results, except ANCOVA for feed intakes).

\begin{tabular}{lccc}
\hline & Clone effect & Diet effect & Clone $\times$ diet effect \\
\hline Period P1 & & & \\
Final weight & $<0.0001$ & $<0.0001$ & $<0.0001$ \\
CV of weight & $<0.0001$ & $<0.0001$ & 0.0005 \\
Feed efficiency & 0.0043 & 0.3214 & 0.0170 \\
Daily feed intake & 0.0051 & $<0.0001$ & $<0.0001$ \\
Mortality (during P1) & 0.15 & 0.21 & 0.79 \\
Period P2 & & & \\
Final weight & & $<0.0001$ & $<0.0001$ \\
CV of weight & $<0.0001$ & $<0.0001$ & 0.0142 \\
Feed efficiency & $<0.0001$ & $<0.0001$ & $<0.0001$ \\
Daily feed intake & $<0.0001$ & $<0.0001$ & $<0.0001$ \\
Mortality (during P2) & $<0.0001$ & $<0.0001$ & 0.0026 \\
& & & \\
Period P3 & & & \\
Mortality (during P3) & $<0.0001$ & $<0.0001$ & $<0.0001$ \\
\hline
\end{tabular}

these parameters was tested with the other effect (diet or clone, respectively) fixed.

\subsection{Diet effect (within each genotype)}

For body weight, the diet effect was significant for each clone $(P<0.04)$. At the end of P1, the clones fed V100 were on average $18 \%$ smaller than those fed V0 and $39 \%$ at the end of P2 (Table 2). The within-clone phenotypic variability, measured as the coefficient of variation of weight (CV), was also affected by the diet, whatever the period, as illustrated by the approximately $20 \%$ smaller CVs in clones fed diet V0 compared to diet V100 (Table 2). The magnitude of CV increase in response to the diet was however not uniform: two clones exhibited a large increase of CV: 79 and $110(P<0.0037)$, while no significant change was noted for clones $83(P>0.29), 97(P>0.16)$ and $120(P>0.13)$. Diet-induced differences in $\mathrm{CV}$ in the other clones were close to the level of significance ( $P$ within $0.05-0.09$ ).

Likewise, feed intakes in each clone were significantly affected by the diet during both periods $(P<0.05)$. At the end of $\mathrm{P} 1$, the clones fed V100 had consumed on average $33 \%$ less feed than those fed diet V0 and $53 \%$ less at the end of P2. For feed efficiency, the diet effect was not significant in $\mathrm{P} 1 \quad(P>0.22)$ except for clones 110 and $120(P<0.03)$ which displayed a lower FE with V100 than with V0 from the beginning of the trial. In P2, FE was significantly affected by the diets in all clones $(P<0.04)$ but for clone $97(P=0.11)$. In this second period, the average FE in clones fed V100 was $28 \%$ lower than when fed V0.

Table 4

Cumulated mortality $(\% \pm S D)$ at the end of period P3 for each rainbow trout clone and each diet.

\begin{tabular}{llll}
\hline Clone & Diet & & $\begin{array}{l}\text { Diet effect } \\
(P \text { value })\end{array}$ \\
\cline { 2 - 3 } & V0 & V100 & \\
\hline 79 & $0.6 \pm 0.5$ & $3.0 \pm 2.1^{\mathrm{E}}$ & 0.09 \\
83 & $1.7 \pm 3.0$ & $6.2 \pm 2.6^{\mathrm{DE}}$ & 0.26 \\
91 & $0.0 \pm 0.0$ & $39.4 \pm 8.6^{\mathrm{AB}}$ & 0.02 \\
97 & $3.3 \pm 1.9$ & $50.6 \pm 8.2^{\mathrm{A}}$ & 0.0004 \\
107 & $1.8 \pm 1.6$ & $25.5 \pm 3.1^{\mathrm{BC}}$ & 0.0005 \\
110 & $0.9 \pm 1.6$ & $13.9 \pm 7.9^{\mathrm{CDE}}$ & 0.02 \\
120 & $2.1 \pm 2.1$ & $16.1 \pm 4.3^{\mathrm{CD}}$ & 0.0061 \\
Clone effect $(P$ value $)$ & 0.21 & $<0.0001$ & \\
\hline
\end{tabular}

Clones with different letters are significantly different $(P<0.05$ ANOVA).
Table 5

Ranking of the rainbow trout clones for body weight, $\mathrm{CV}$ of body weight, feed intake and feed efficiency in periods 1 and 2 .

\begin{tabular}{|c|c|c|c|c|c|}
\hline \multicolumn{3}{|c|}{ Period 1 (P1) } & \multicolumn{3}{|c|}{ Period 2 (P2) } \\
\hline Group & $\begin{array}{l}\text { Range of } \\
\text { mean values }\end{array}$ & Clone & Group & $\begin{array}{l}\text { Range of } \\
\text { mean values }\end{array}$ & Clone \\
\hline \multicolumn{6}{|c|}{ Body weight (g) for V0 } \\
\hline A & 3.21 & 110 & A & 6.52 & 110 \\
\hline B & 3.06 & 107 & B & 5.44 & 107 \\
\hline C & $2.82-2.87$ & 83,120 & C & 5.22 & 83 \\
\hline $\mathrm{D}$ & 2.67 & 91,97 & $\mathrm{CD}$ & 5.14 & 120 \\
\hline \multirow[t]{2}{*}{$\mathrm{E}$} & 2.47 & 79 & $\mathrm{D}$ & 5.03 & 91 \\
\hline & & & $\mathrm{E}$ & $4.51-4.63$ & 97,79 \\
\hline \multicolumn{6}{|c|}{ Body weight (g) for V100 } \\
\hline A & 2.64 & 83,107 & A & 4.02 & 83 \\
\hline B & 2.52 & 120 & B & 3.55 & 107 \\
\hline C & 2.34 & 97 & C & 2.27 & 120 \\
\hline $\mathrm{D}$ & 2.12 & 91 & $\mathrm{D}$ & 3.11 & 97 \\
\hline \multirow[t]{2}{*}{$\mathrm{E}$} & $1.94-2.02$ & 110,79 & $\mathrm{E}$ & $2.80-2.85$ & 79,110 \\
\hline & & & $\mathrm{F}$ & 2.52 & 91 \\
\hline \multicolumn{6}{|c|}{$C V(\%)$ for $V 0$} \\
\hline A & 21.6 & 97 & A & 21.9 & 97 \\
\hline $\mathrm{AB}$ & 20.4 & 107 & $\mathrm{AB}$ & $18.2-21.4$ & $\begin{array}{l}107,91,110, \\
120,79\end{array}$ \\
\hline $\mathrm{ABC}$ & $17.7-19.2$ & $110,91,120$ & B & 16.9 & 83 \\
\hline BC & 16.4 & 79 & & & \\
\hline $\mathrm{C}$ & 15.5 & 83 & & & \\
\hline \multicolumn{6}{|c|}{ CV (\%) for V100 } \\
\hline A & 30.1 & 110 & A & 31.5 & 110 \\
\hline B & $22.9-23.4$ & $\begin{array}{l}91,107 \\
97,79\end{array}$ & $\mathrm{AB}$ & $26.4-27.1$ & 107,91 \\
\hline $\mathrm{BC}$ & 21.4 & 120 & $\mathrm{ABC}$ & $23.5-24.1$ & 97,79 \\
\hline \multirow[t]{2}{*}{ C } & 17.1 & 83 & $\mathrm{BC}$ & 23.0 & 120 \\
\hline & & & C & 17.9 & 83 \\
\hline \multicolumn{6}{|c|}{ Daily feed intake ( $m g$ per ind) for Vo } \\
\hline A & 68 & 110 & A & 122 & 110 \\
\hline $\mathrm{AB}$ & 59 & 107 & B & $90-98$ & $\begin{array}{l}107,120 \\
97,91,83\end{array}$ \\
\hline B & $50-56$ & $\begin{array}{l}120,91,97 \\
83,79\end{array}$ & C & 79 & 79 \\
\hline \multicolumn{6}{|c|}{ Daily feed intake ( $m g$ per ind) for V100 } \\
\hline A & $42.1-45$ & $107,120,83$ & A & 59.4 & 83 \\
\hline $\mathrm{AB}$ & 39.8 & 97 & $\mathrm{AB}$ & 52.3 & 107 \\
\hline $\mathrm{BC}$ & 35 & 91 & $\mathrm{BC}$ & 45.2 & 120 \\
\hline \multirow[t]{3}{*}{$c$} & $30.1-31.6$ & 110,79 & $\mathrm{BCD}$ & 41.8 & 79,110 \\
\hline & & & $\mathrm{CD}$ & $39.8-41.6$ & 97 \\
\hline & & & $\mathrm{D}$ & 32.9 & 91 \\
\hline \multicolumn{6}{|c|}{ Feed efficiency for Vo } \\
\hline \multirow[t]{3}{*}{ A } & $1.20-1.30$ & All & A & $1.11-1.22$ & $\begin{array}{l}110,83,79, \\
91,107\end{array}$ \\
\hline & & & A & 1.10 & 120 \\
\hline & & & B & 0.96 & 97 \\
\hline \multicolumn{6}{|c|}{ Feed efficiency for V100 } \\
\hline A & 1.38 & 83 & A & 1.05 & 83 \\
\hline$A B$ & $1.21-1.32$ & $\begin{array}{l}91,120,107 \\
97,79\end{array}$ & $A B$ & $0.77-0.99$ & $\begin{array}{l}79,110,97 \\
107\end{array}$ \\
\hline \multirow[t]{2}{*}{ B } & 1.11 & 110 & $\mathrm{BC}$ & 0.74 & 120 \\
\hline & & & C & 0.47 & 91 \\
\hline
\end{tabular}

For each trait and each period, groups with different letters are significantly different $(P<0.05$ ANOVA or ANCOVA for feed intakes).

\subsection{Genotype effect (within each dietary group)}

Table 5 shows the genotype effect on the growth-related parameters. The analyses revealed, when diet effect is fixed, a significant $(P<0.05)$ clone effect for body weight, DFI and FE, except for $\mathrm{FE}$ in $\mathrm{P} 1$ with V0. Considering the $\mathrm{CV}$, the clone effect was also significant for each period and each diet $(P<0.02)$. 
a

$\rightarrow \sim \mathrm{C} 107-\mathrm{C} 110-\mathrm{-}-\mathrm{C} 120-\mathrm{C} 79 \rightarrow \mathrm{C} 83 \rightarrow-\mathrm{C} 91 \rightarrow \mathrm{C} 97$

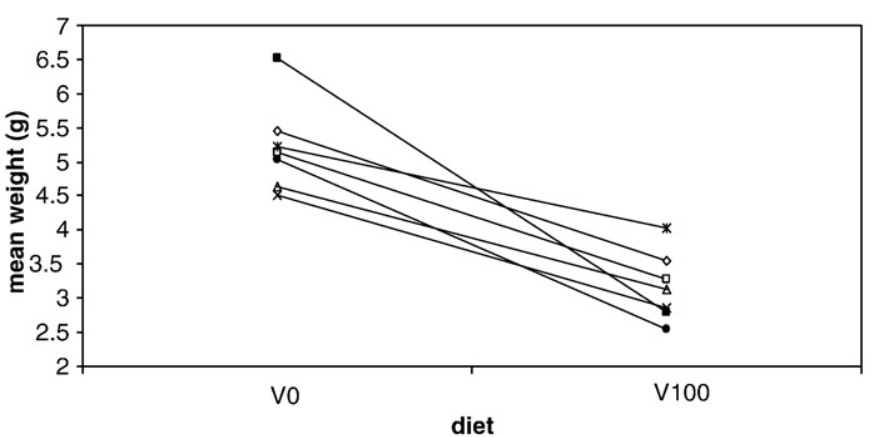

b $\rightarrow$ C $107-* \mathrm{C} 110-\mathrm{a}-\mathrm{C} 120-\mathrm{C} 79-\mathrm{*}-\mathrm{C} 83 \rightarrow-\mathrm{C} 91-\mathrm{C} 97$

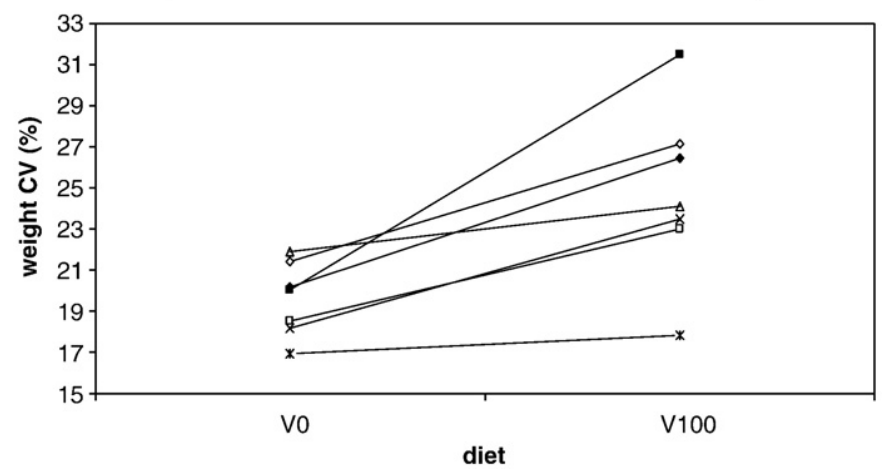

Fig. 2. Mean body weight (a) and weight CV (b) at the end of period 2 for each rainbow trout clone fed diet V0 (fishmeal diet) or diet V100 (plant-based diet).

\subsection{Genotype-diet interactions}

Genotype-diet interactions were highly significant for all traits (Table 3). These interactions are illustrated in Fig. 2 for body weight (a) and body weight CV (b) at P2 and in Table 5, showing multiple inversions of genotype rankings for all traits between both diets. For example, in P2, clone 110 fed diet V0 had the best growth $(+20 \%$ compared to the second best clone in P2), the highest feed intake and a very high FE. However, this clone had a depressed performance with diet V100. Clone 83 showed a different response, displaying intermediate performances with diet $\mathrm{V} 0$ but the best growth with diet V100 (related to a higher feed intake and good FE, Table 5). Moreover, these clones exhibited a different response to the diet in terms of phenotypic variability. In clone 110, diet V100 increased the variability of weight ( $+50 \%$ relative increase), in contrast to clone 83 , in which the $\mathrm{CV}$ remained almost unchanged, irrespective of the diet. It is noteworthy that genotype-diet interactions remained significant, even after the removal of a clone with a strong response to diet (e.g. clone 110) from the analysis, underlying interaction as an intrinsic feature of the results.

The ranking of the clones was well conserved between both periods for final weight and CV (Table 5). For DFI, the ranking between both periods was well conserved with diet V0 and less with diet V100. For FE, the rankings between both periods could not be compared for fish fed V0, as there was no significant difference between the clones in the first period. With V100, the ranking of the clones based on FE was only partially conserved between P1 and P2.

\section{Discussion}

\subsection{Dietary effect}

The plant-based diet reduced growth as compared to the fishmeal diet in all clones, despite the selection of high quality plant-protein sources and the correction of the essential amino acid deficiency. This reduction in growth at the end of P2 was between 23\% and 57\% depending on the genotype. This growth limitation is higher than in most other studies on fishmeal replacement in rainbow trout (Refstie et al., 2000; Yamamoto et al., 2002; Barrows et al., 2007), including those from our laboratory (Kaushik et al., 1995; Médale et al., 1998; Mambrini et al., 1999). The drastic dietary effect, reflected also in reduced survival, is likely to be attributed to the deliberately chosen combination of a complete fishmeal substitution together with the small fish size, rather than, as in the majority of above cited studies, a partial substituted diet and fish of larger sizes, less susceptible to the diet. Indeed, veterinary controls identified no specific disease associated with mortalities. Moreover, the mean performances (feed intake and feed efficiency) of the heterozygous clones fed the fishmeal diet were in the range of those recorded in non-clonal trout, indicating that the tested clones were not particularly compromised in terms of feed utilization potential. The impact of plant-based diets on health and well-being constitutes here an interesting and complementary research question.

The reductions in growth with the plant-based compared to the fishmeal-based diet were significant from the first period and further accentuated towards the end of the second period. The same was seen for voluntary feed intakes. This suggests that the lower growth was not the result of a temporary adaptation problem to the plant-based diet, as suggested before with larger trout fed a soybean meal-based diet (Refstie et al., 1997). Reduced feed intakes, due to palatability problems, have been reported frequently in fish fed plant-based diets (Gomes et al., 1995; Mambrini et al., 1999; Espe et al., 2006). Palatability can be defined as the overall impression of a diet by all the animal's senses and is determined by the experience and metabolic status of the animal and the orosensory properties of the feed (Forbes, 1995). However, orosensory dislikes, mostly detected in choice tests, are not necessarily expressed when the food is given separately. This was also seen in rainbow trout fed diets with various feed oils, where the lower preference for the diet with linseed oil relative to fish oil (Geurden et al., 2005) did not significantly affect the actual intakes of these diets in a no-choice trial (Geurden et al., 2007). Moreover, orosensory dislikes are often found to be temporary (Forbes, 1995). Since feed intakes in our study remained persistently lower, without visible adaptation to the plant-based diet, they are more likely to be attributed to an adverse post-ingestive or metabolic effect rather than to an orosensory dislike of the plant proteins, an issue requiring however further confirmation.

Also the observation that feed efficiency was adversely affected by the plant-based diet suggests a post-ingestive or metabolic alteration, but only significant during period 2 . The reduction in feed efficiency due to fishmeal replacement is in agreement with findings from other trials with rainbow trout (Adelizi et al., 1998; de Francesco et al., 2004; Barrows et al., 2007) and might be due to disturbed digestive or modified metabolic processes (Krogdahl et al., 2003; Vilhelmsson et al., 2004), possibly in relation with the presence of anti-nutritional factors in plant ingredients.

\subsection{Genotype effect}

Our data demonstrate an important genetic variability among the seven genotypes for all traits within the groups fed the plant-based diet as well as within the groups fed the fishmeal-based diet. This result is enhanced by the consistency, within each diet, in the ranking order of the clones between both periods for all traits, except FE. The low consistency of rankings for FE is in line with the generally low heritability estimates of FE reported in the fish literature (Kinghorn, 1983; Henryon et al., 2002; Quinton et al., 2007a,b).

Only few studies with fish documented genetic variability (between strains or families) in the response to plant-based diets. For rainbow trout, genetic variability was found for growth using a 
diet low in fishmeal (Smith et al., 1988), or a diet with corn and wheat gluten and 10\% krill (Palti et al., 2006), or with a diet with corn gluten, wheat gluten, soybean meal and 5\% krill (Pierce et al., 2008). Genetic variability was also reported for growth in European whitefish fed a diet with $25 \%$ soybean meal and $25 \%$ fishmeal (Quinton et al., 2007b). Only two papers investigated the genetic variability of the two major growth determinants (DFI and FE) and provided results consistent with ours, i.e. genetic variability exists for both traits (Quinton et al., 2007a,b).

Our study also provides original results on the level of phenotypic variability when feeding plant-based diets. Despite the genetic identity of all individuals within a clone, feeding the plant-based diet increased the phenotypic variability in most clones, reflecting the reduced acceptance of plant protein. It follows that the growth performance of a given genotype (a clone here, an individual in a classical population) when fed plant-based diets may become quite unpredictable. This may not only increase the overall phenotypic variability in commercial stocks, but also decrease the precision of breeding value estimates compared to a classical diet. This observation also points out the need for further studies on the physiological status and health of trout fed plant-based diets.

Taken together, all these results suggest that parameters related to growth and its determinants (DFI and to a lesser extent FE) with plant-based diets can be selected, which may help the transition towards new aquafeed.

\subsection{Genotype-diet interactions}

The major finding in this study is the high genotype $\times$ diet interaction for all traits (except mortality which was close to zero for all clones fed with $\mathrm{V} 0$ ), illustrated by the important re-rankings of the clones between both experimental diets. This finding contrasts with most other studies examining genotype-diet interactions, related e.g. to the level of protein or carbohydrate (Austreng et al., 1977; Blanc, 2002). With regard to the dietary protein source, Smith et al. (1988) reported that the growth differences among 10 rainbow trout strains, fed a diet rich in either plant or fishmeal protein, were affected by the strain but not by the protein source (no strain $\times$ diet interaction). Similarly, recent feeding trials with salmonids designed for the study of a family interaction with dietary protein source (Palti et al., 2006; Quinton et al., 2007a,b) concluded that current fish breeding programs which select for growth on fishmeal-based diets should also improve the broodstock's ability to use alternative proteins. The latter authors however used a partially substituted diet during the whole experiment (Smith et al., 1988; Quinton et al., 2007a,b) or during early growth (until 25 g, Palti et al., 2006), which might have masked the interaction. Our results agree with two recent studies in channel catfish, Ictalurus punctatus (Li et al., 2006) and rainbow trout (Pierce et al., 2008), where the genotype $\times$ protein source interaction for growth rate was found to be, respectively, slightly or highly significant. In Pierce et al. (2008), almost all marine protein was substituted by a blend of soybean meal and gluten (corn and wheat), leaving only $5 \%$ in the form of krill as attractant, and part of fish oil was substituted with soybean oil. Moreover this diet was given from first-feeding. These could be the reasons why, as in the present study, significant interactions were found.

In summary, the present study shows the existence of genotype $\times$ diet interactions using different protein sources. Thus, rainbow trout selected for high growth with a conventional fishmeal-based diet may not necessarily display optimal performances with plantbased diets, at least when fed an extreme diet devoid of fishmeal during early growth. In addition, genotype $\times$ diet interactions were also noted for the within-clone variability in growth (CV) and for both growth determinants, i.e. daily feed intake and feed efficiency, which raise further issues for improving the use of plant-based diets by rainbow trout

\section{References}

Adelizi, P.D., Rosati, R.R., Warner, K., Wu, Y.V., Muench, T.R., White, M.R., Brown, P.B 1998. Evaluation of fish-meal free diets for rainbow trout, Onchorynchus mykiss. Aquac. Nutr. 4, 255-266.

Austreng, E., Risa, S., Edwards, D.J., Hvidsten, H., 1977. Carbohydrate in rainbow trout diets. II. Influence of carbohydrate levels on chemical composition and feed utilization of fish from different families. Aquaculture 11, 39-50.

Barrows, F.T., Gaylord, T.G., Stone, T.A.J., Smith, C.E., 2007. Effect of protein source and nutrient density on growth efficiency, histology and plasma amino acid concentration of rainbow trout (Oncorhynchus mykiss Walbaum). Aquac. Res. 38, $1747-1758$.

Blanc, J.M., 2002. Interaction between diet and genetic aptitude for weight and growth in juvenile rainbow trout, Oncorhynchus mykiss (Walbaum). Aquac. Res. 8, 563-568.

Carter, G.C., Hauler, R.C., 2000. Fish meal replacement by plant meals in extruded feeds for Atlantic salmon, Salmo salar L. Aquaculture 185, 299-311.

de Francesco, M., Parisi, G., Médale, F., Lupi, P., Kaushik, S., Poli, B.M., 2004. Effect of longterm feeding with a plant protein mixture based diet on growth and body/fillet quality traits of large rainbow trout (Oncorhynchus mykiss). Aquaculture 236, 413-429.

Espe, M., Lemme, A., Petri, A., El-Mowafi, A., 2006. Can Atlantic salmon (Salmo salar) grow on diets devoid of fish meal? Aquaculture 255, 255-262.

Forbes, J.M., 1995. Voluntary food intake and diet selection in farm animals. CAB International, Wallingford, Oxon, UK. 532 pp.

Gatlin, D.M., Barrows, F.T., Brown, P., Dabrowski, K., Gaylord, T.G., Hardy, R.W., Herman, E.M., Hu, G., Krogdahl, A., Nelson, R., Overturf, K., Rust, M.B., Sealey, W.M., Skonberg, D., Souza, E.J., Stone, D. Wilson, R., Wurtele, E. 2007. Expanding the utilization of sustainable plant products in aquafeeds: a review. Aquac. Res. 38, 551-579.

Geurden, I., Cuvier, A., Gondouin, E., Olsen, R.E., Ruohonen, K., Kaushik, S., Boujard, T., 2005. Rainbow trout can discriminate between feeds with different oil sources. Physiol. Behav. 85, 107-114.

Geurden, I., Corraze, G., Boujard, T., 2007. Self-feeding behaviour of rainbow trout, Oncorhynchus mykiss, offered diets with distinct feed oils. Appl. Anim. Behav. Sci. 108, 313-326.

Gomes, E.F., Rema, P., Kaushik, S.J., 1995. Replacement of fish meal by plant protein in the diet of rainbow trout (Oncorhynchus mykiss): digestibility and growth performance. Aquaculture 130, 177-186.

Grima, L., Quillet, E., Boujard, T., Robert-Granié, C., Chatain, B., Mambrini, M., 2008 Genetic variability in residual feed intake in rainbow trout clones and testing of indirect selection criteria. Genet. Sel. Evol. 40, 607-624.

Henryon, M., Jokumsen, A., Berg, P., Lund, I., Pedersen, P.B., Olesen, N.J., Slierendrecht, W.J., 2002. Genetic variation for growth rate, feed conversion efficiency and disease resistance exists within a farmed population of rainbow trout. Aquaculture 209, 59-76.

Kaushik, S.J., Cravedi, J.P., Lalles, J.P., Sumpter, J., Fauconneau, B., Laroche, M., 1995. Partial or total replacement of fish meal by soybean protein on growth, protein utilization, potential estrogenic effects, cholesterolemia and flesh quality in rainbow trout Aquaculture 133, 257-274.

Kinghorn, B.P., 1983. A review of quantitative genetics in fish breeding. Aquaculture 31, 283-304.

Krogdahl, A.., Bakke-McKellep, A.M., Baeverfjord, G., 2003. Effects of graded levels of standard soybean meal on intestinal structure, mucosal enzyme activities, and pancreatic response in Atlantic salmon (Salmo salar L.). Aquac. Nutr. 9, 361-371.

Li, M.H., Peterson, B.C., Janes, C.L., Robinson, E.H., 2006. Comparison of diets containing various fish meal levels on growth performance, body composition, and insulin-like growth factor-I of juvenile channel catfish Ictalurus punctatus of different strains. Aquaculture 253, 628-635.

Mambrini, M., Roem, A.J., Cravedi, J.P., Lallès, J.P., Kaushik, S.J., 1999. Effects of replacing fish meal with soy protein concentrate and of DL-methionine supplementation in high-energy, extruded diets on the growth and nutrient utilization of rainbow trout, Oncorhynchus mykiss. J. Anim. Sci. 77, 2990-2999.

Médale, F., Boujard, T., Vallée, F., Blanc, D., Mambrini, M., Roem, A., Kaushik, S.J., 1998 Voluntary feed intake, nitrogen and phosphorus losses in rainbow trout (Oncorhynchus mykiss) fed increasing dietary levels of soy protein concentrate. Aquat. Living Resour. 11, 239-246.

Naylor, R.L., Goldburg, R.J., Primavera, J.H., Kautsky, N., Beveridge, M.C.M., Clay, J., Folke, C., Lubchenco, J., Mooney, H., Troell, M., 2000. Effect of aquaculture on world fish supplies. Nature 405, 1017-1024.

NRC (National Research Council), 1993. Nutrient Requirements of Fish. National Academy Press, Washington, DC, USA. 114 pp.

Palti, Y., Silverstein, J.T., Wieman, H., Philips, J.G., Barrows, F.T., Parsons, J.E., 2006 Evaluation of family growth response to fishmeal and gluten-based diets in rainbow trout (Oncorhynchus mykiss). Aquaculture 255, 548-556.

Pierce, L.R., Palti, Y., Silverstein, J.T., Barrows, F.T., Hallerman, E.M., Parsons, J.E., 2008 Family growth response to fishmeal and plant-based diets shows genotype $\times$ diet interaction in rainbow trout (Oncorhynchus mykiss). Aquaculture 278, 37-42.

Quillet, E., Dorson, M., Le Guillou, S., Benmansour, A., Boudinot, P., 2007. Wide range of susceptibility to rhabdoviruses in homozygous clones of rainbow trout. Fish Shellfish Immunol. 22, 510-519.

Quinton, C.D., Kause, A., Koskela, J., Ritola, O., 2007a. Breeding salmonids for feed efficiency in current fishmeal and future plant-based diet environments. Genet. Sel. Evol. 39, 431-446.

Quinton, C.D., Kause, A., Ruohonen, K., Koskela, J., 2007b. Genetic relationships of body composition and feed utilization traits in European whitefish (Coregonus lavaretus L.) and implications for selective breeding in fishmeal and soybean mealbased diet environments. J. Anim. Sci. 85, 3198-3208.

Refstie, S., Helland, S.J., Storebakken, T., 1997. Adaptation to soybean meal in diets for rainbow trout, Oncorhynchus mykiss. Aquaculture 153, 263-272. 
Refstie, S., Korsoen, O.J., Storebakken, T., Baeverfjord, G., Lein, I., Roem, A.J., 2000. Differing nutritional responses to dietary soybean meal in rainbow trout (Oncorhynchus mykiss) and Atlantic salmon (Salmo salar). Aquaculture 190, 49-63. Smith, R.R., Kincaid, H.L., Regenstein, J.M., Rumsey, G.L., 1988. Growth, carcass composition, and taste of rainbow trout of different strains fed diets containing primarily plant or animal protein. Aquaculture 70, 309-321.

Storebakken, T., Shearer, K.D., Roem, A.J., 2000. Growth, uptake and retention of nitrogen and phosphorus, and absorption of other minerals in Atlantic salmon Salmo salar fed diets with fish meal and soy-protein concentrate as the main sources of protein. Aquac. Nutr. 6, 103-108.
Vilhelmsson, O.T., Martin, S.A.M., Médale, F., Kaushik, S.J., Houlihan, D.F., 2004. Dietary plant-protein substitution affects hepatic metabolism in rainbow trout (Oncorhynchus mykiss). Br. J. Nutr. 92, 71-80.

Watanabe, T., Verakunpiriya, V., Watanabe, K., Viswanath, K., Satoh, S., 1998. Feeding of rainbow trout with non-fish meal diets. Fish. Sci. 63, 258-266.

Yamamoto, T., Shima, T., Furuita, H., Suzuki, N., 2002. Influence of feeding diets with and without fish meal by hand and by self-feeders on feed intake, growth and nutrient utilization of juvenile rainbow trout (Oncorhynchus mykiss). Aquaculture 214, 289-305 